\title{
ANALISA FAKTOR PENENTU TINGKAT KEPUASAN PASIEN DI RUMAH SAKIT PKU MUHAMMADIYAH BANTUL
}

\author{
Wijayanti Puji Lestari1, Sunarto², Titik Kuntari3
}

\begin{abstract}
:
Growing of emulation between hospitals that is increasingly tight and sharply, hence every hospital claimed to heighten competitiveness by trying gives satisfaction to all the patients. For the purpose must be known factors which influencing level of satisfaction of the patient. And is a real thing necessary for we to know what which patient we require to fulfill their satisfaction to services which we give. This research aim to know factors determining satisfaction of patient takes care of lodging and installation of emergency, also knows is there is difference of determinant level of satisfaction between patients takes care of lodging, and installation of emergency. This research done in PKU Muhammadiyah Bantul Hospital. This research applies cross sectional research planning. Sampling method in this research is systematic random sampling.Instrument of research applied is questionair, containing patient characteristic, satisfaction determinant factors of patient, as well as satisfaction of patient. Analysis by using SPSS for windows15. Result show that determinant level of satisfaction most importantly in determining level of satisfaction of responder takes care of lodging and installation of emergency is factor reliability. Determinant level of satisfaction of patient to take care of lodging sorted from most importantly is, reliability, assurance, accessibility, responsiveness, tangible, and last of empathy. Determinant level of satisfaction of patient for IGD sorted from most importantly is, reliability, tangible, responsiveness, acc essibility, assurance, and last, empathy. For takes care of lodging responder, men gender, age more than 25 years old, lower education or SMA, and production of Rp.799.999 or less, tends to satisfying to Hospital service, but it doesn't have a meaning statistically. For installation responder of Emergency, men gender, age more than 25 years old, higher education from SMA, and production more than Rp. 799999,- tends to satisfying to Hospital service, but it doesn't have a meaning statistically.
\end{abstract}

\section{Keywords : Satisfaction determinants, PKU MUHAMMADIYAH BANTUL}

\section{ABSTRAK}

Tumbuhnya persaingan antar rumah sakit yang semakin ketat dan tajam sehingga setiap rumah sakit dituntut untuk mempertinggi daya saing dengan berusaha memberikan kepuasan kepada semua pasiennya. Untuk itu harus diketahui faktor - faktor apa sajakah yang mempengaruhi tingkat kepuasan pasien tersebut. Dan merupakan suatu hal yang sangat penting bagi kita untuk mengetahui apa yang pasien butuhkan untuk memenuhi kepuasan mereka terhadap pelayanan yang kita berikan. Penelitian ini bertujuan untuk mengetahui faktor-faktor yang menentukan kepuasan pasien rawat inap dan instalasi gawat darurat, juga mengetahui apakah terdapat perbedaan faktor penentu tingkat kepuasan antara pasien rawat inap, dan instalasi gawat darurat. Penelitian ini dilakukan di RS PKU Muhammadiyah Bantul. Penelitian ini menggunakan rancangan penelitian cross sectional. Metode pengambilan sampel dalam penelitian ini adalah metode probability sampling jenis acak sistematis. Instrumen penelitian yang digunakan adalah kuisioner yang berisi data karakteristik pasien, faktor-faktor penentu kepuasan pasien, dan juga kepuasan pasien. Analisa dengan menggunakan SPSS for windows.15. Hasil menunjukkan faktor penentu yang paling penting dalam menentukan tingkat kepuasan responden rawat inap dan instalasi gawat darurat adalah faktor reliability. Faktor penentu tingkat kepuasan pasien untuk rawat inap diurutkan dari yang paling penting adalah, reliability, assurance, accesibility, responsiveness, tangible, dan terakhir empathy. Faktor penentu tingkat kepuasan pasien untuk IGD diurutkan dari yang paling penting adalah, reliability, tangible, responsiveness, accesibility, assurance, dan terakhir, empathy. Untuk responden Rawat Inap, jenis kelamin laki-laki, umur 18-25 tahun, pendidikan lebih rendah atau SMA, dan penghasilan Rp.799.999,- atau kurang, cenderung puas terhadap pelayanan Rumah Sakit, tetapi hal tersebut tidak bermakna secara statistik. Untuk

\footnotetext{
${ }_{1}^{1}$ Mahasiswa Fakultas Kedokteran Universitas Islam Indonesia

2 Departemen IImu Kesehatan Masyarakat FK UII, narto_darsono@yahoo.com

3 Departemen IImu Kesehatan Masyarakat FK UII, t_kuntari@yahoo.com
} 
Responden instalasi gawat darurat, jenis kelamin laki-laki, umur lebih dari 25 tahun, pendidikan lebih tinggi dari SMA, dan penghasilan lebih dari Rp. 799.999,- cenderung puas terhadap pelayanan Rumah Sakit, tetapi hal tersebut tidak bermakna secara statistik.

Kata Kunci : Faktor penentu kepuasan, RS PKU Muhammadiyah Bantul

PENDAHULUAN

Berkembangnya jumlah rumah sakit di Jogjakarta menjadikan masyarakat Jogjakarta memiliki banyak pilihan untuk menentukan rumah sakit mana yang akan mereka pilih. Masyarakat akan memilih rumah sakit yang mereka pandang memberikan kepuasan yang maksimal bagi mereka. Oleh karenanya diharapkan setiap rumah sakit hendaknya berorientasi pada kepuasan pasien untuk dapat bersaing dengan rumah sakit lain.

Lamri (1997) dalam hasil penelitiannya di RS Islam Samarinda mengatakan bahwa pengaruh kualitas pelayanan terhadap kepuasan pasien dan pengaruh kepuasan terhadap minat untuk menggunakan kembali RS Islam Samarinda adalah kuat dan positif. Hal ini memberikan gambaran untuk kita semua, bahwa kualitas pelayanan yang diberikan oleh pihak rumah sakit akan memberikan pengaruh yang besar bagi kepuasan pasien, sehingga untuk memberikan kepuasan bagi pasiennya setiap rumah sakit harus memberikan pelayanan yang memuaskan 1 .

Tumbuhnya persaingan antar rumah sakit yang semakin ketat dan tajam, maka setiap rumah sakit dituntut untuk mempertinggi daya saing dengan berusaha memberikan kepuasan kepada semua pasiennya. Untuk itu harus diketahui faktor - faktor apa sajakah yang mempengaruhi tingkat kepuasan pasien tersebut. Dan merupakan suatu hal yang sangat penting bagi kita untuk mengetahui apa yang pasien kita butuhkan untuk memenuhi kepuasan mereka terhadap pelayanan yang kita berikan.

Penelitian - penelitian sebelumnya tentang kepuasan pasien telah banyak menjelaskan bahwa terdapat beberapa faktor penentu kepuasan pasien, antara lain yaitu tangibles (aspek yang terlihat secara fisik, misal peralatan dan personel), reliability (kemampuan untuk memiliki perfoma yang bisa diandalkan dan akurat), responsiveness ( kemauan untuk merespon keinginan atau kebutuhan akan bantuan dari pelanggan, serta pelayanan yang cepat ), assurance (kemauan para personel untuk menimbulkan rasa percaya dan aman kepada pelanggan ), empathy (kemauan personel untuk peduli dan memperhatikan setiap pelanggan). Selain itu juga terdapat beberapa variabel nonmedik yang juga dapat mempengaruhi kepuasan pasien, diantaranya yaitu: tingkat pendidikan, latar belakang sosial ekonomi, budaya, lingkungan fisik, pekerjaan, kepribadian dan lingkungan hidup, juga dipengaruhi oleh karakteristik pasien, yaitu: umur, pendidikan, pekerjaan, etnis, sosial ekonomi, dan diagnosis penyakit 2,3.

Rumah Sakit PKU Muhammadiyah Bantul adalah sebuah Rumah Sakit swasta yang sedang berkembang yang ada di wilayah kota Bantul, tepatnya di J I. Jendral sudirman 124 Bantul. Rumah Sakit ini didirikan pertama kali pada tanggal 1 Maret 1966, berawal dari sebuah Balai Pengobatan dan Rumah Bersalin yang kemudian pada tanggal 21 
Agustus 1995 menjadi Rumah Sakit Khusus lbu dan Anak, dan pada tahun 2001 resmi menjadi Rumah Sakit Umum type $C$ dengan jumlah tempat tidur sebanyak 104. Rumah Sakit ini memiliki 246 orang karyawan tetap, 26 orang karyawan honorer, dan 4 orang karyawan tidak tetap, sedangkan jumlah dokter umumnya saat ini berjumlah 19 orang dan dokter spesialis 61 orang.

Pelayanan yang disediakan oleh Rumah Sakit PKU Muhammadiyah Bantul sudah cukup lengkap, terdiri dari pelayanan $24 \mathrm{~J}$ am yang berupa Instalasi Gawat Darurat (IGD), rawat inap, ICU, pelayanan bersalin, pelayanan operasi, pelayanan rukti jenazah dan juga circumsisi. Pelayanan penunjang medik yang tersedia antara lain: laboratorium klinik, farmasi, radiology, Ambulan 118 dan PKU DMC, juga pelayanan gizi. RS PKU Muhammadiyah Bantul juga memiliki pelayanan poliklinik yang dibuka setiap hari Senin hingga Sabtu, yang terdiri dari poliklinik anak, penyakit dalam, kebidanan dan penyakit dalam, bedah ( umum, orthopedic, anak, digestive, thorax dan vasculer, dan mulut), syaraf, jiwa, kulit kelamin, THT, gigi, mata, tumbuh kembang anak, umum, fisioterapi dan juga poliklinik Bidan. Rumah Sakit ini juga memiliki pelayanan lain yang berupa club lansia, club diabetes, tes bebas narkoba, senam hamil, pelayanan informasi obat, konsultasi gigi, pelayanan home care, pelayanan akte kelahiran, dan juga General Medical Check up (GMC).

Untuk bisa berkembang dengan baik, RS harus memperhatikan kepuasan pelanggan. Penelitian ini bertujuan untuk mengetahui faktor-faktor penentu tingkat kepuasan pasien rawat inap, dan
Instalasi Gawat Darurat di RS PKU Muhammadiyah Bantul serta mengetahui apakah terdapat perbedaan faktor penentu tingkat kepuasan antara pasien rawat inap, dan Instalasi Gawat Darurat di RS PKU Muhammadiyah Bantul.

Metode Penelitian

Penelitian ini merupakan penelitian non eksperimental dengan desain cross sectional. Populasi penelitian ini adalah seluruh pasien rawat inap, dan IGD di RS PKU Muhammadiyah Bantul. Sampel pada penelitian ini yaitu pasien rawat inap, dan IGD yang memenuhi kriteria-kriteria yang sudah ditentukan, yaitu:

Kriteria inklusi :

1. untuk pasien rawat inap, adalah pasien yang telah dirawat $3 \times 24$ jam

2. dapat berkomunikasi dengan baik

3. tidak ada gangguan jiwa

4. bersedia sebagai responden dalam penelitian

Cara pemilihan sampel penelitian didasarkan pada metode probability sampling, jenis acak sistematis. Setiap pasien rawat inap, dan IGD yang ada di RS PKU Muhammadiyah Bantul yang memenuhi kriteria dapat dimasukkan sebagai subjek penelitian. J umlah sampel penelitian untuk digunakan sebagai data ditetapkan berdasarkan nilai sampel minimal menurut Fraenkel dan Wallen adalah 30 untuk rawat inap dan $\mathbf{3 0}$ untuk IGD.

Variabel-variabel yang digunakan dalam penelitian ini adalah:

1. variabel independen : faktor penentu tingkat kepuasan pasien (tangibles, reliability, responsiveness, assurance, empathy, accessibility), 
karakteristik pasien (jenis kelamin, umur, pekerjaan, pendidikan dan juga penghasilan).

2. variabel dependen : kepuasan pasien.

Instrumen penelitian adalah kuisioner untuk mendapatkan data primer penelitian. Data yang tercantum dalam kuisioner tersebut antara lain data karakteristik pasien (Jenis kelamin, Umur, Tingkat pendidikan, Pekerjaan, Penghasilan), Faktor penentu kepuasan pasien (tangibles, reliability, responsiveness, assurance, empathy, accessibility) serta Kepuasan pasien. Kuisioner ini diambil dan disarikan dari kuisioner penelitian Surya wati,dkk (2006) yang berjudul Penyusunan Indikator Kepuasan Pasien Rawat Inap Rumah Sakit Di Provinsi Jawa Tengah. Sedangkan untuk reliabilitas dari kuisioner ini telah peneliti uji menggunakan rumus Alpha dan didapatkan r11: 0,9131, yang berarti bahwa reliabilitas kuisioner tersebut tinggi ${ }^{4}$. Kuisioner dibagikan kepada pasien yang memenuhi kriteria sebagai sampel penelitian, dan bersedia mengisi kuisioner tersebut. Kemudian setelah pasien selesai mengisi kuisioner tersebut, dikumpulkan, kemudian dicek kelengkapan data yang ada.

Hasil dan Pembahasan

Karakteristik Responden

Penelitian ini dilaksanakan di Rumah Sakit PKU Muhammadiyah Bantul pada bulan April 2008, dimana yang dijadikan subjek penelitian adalah pasien rawat inap dan IGD yang memenuhi kriteria inklusi. Total responden adalah 60 responden, 30 untuk pasien rawat inap dan 30 untuk pasien IGD, dengan karakteristik yang berbeda-beda. Dari 60 responden tersebut didapatkan data sebagai berikut :

pasien rawat inap

Tabel 1 Karakteristik Responden

\begin{tabular}{|c|c|c|c|c|}
\hline \multirow{2}{*}{ Karakteristik } & \multicolumn{2}{|c|}{ IGD } & \multicolumn{2}{|c|}{ Rawat Inap } \\
\hline & $\mathbf{N}$ & Persen & $\mathbf{N}$ & Persen \\
\hline J enis Kelamin & & & & \\
\hline $\begin{array}{ll}\text { - } & \text { laki-laki } \\
\text { - } & \text { perempuan }\end{array}$ & $\begin{array}{l}17 \\
13\end{array}$ & $\begin{array}{l}56,7 \\
43,3\end{array}$ & $\begin{array}{l}18 \\
12\end{array}$ & $\begin{array}{l}60,0 \\
40,0\end{array}$ \\
\hline Usia & & & & \\
\hline $\begin{array}{ll}- & \text { 18-25 tahun } \\
- & \text { 25-65 tahun } \\
- & >65 \text { tahun }\end{array}$ & $\begin{array}{r}7 \\
23 \\
0\end{array}$ & $\begin{array}{r}23,3 \\
76,7 \\
0,0\end{array}$ & $\begin{array}{r}9 \\
18 \\
3\end{array}$ & $\begin{array}{l}30,0 \\
60,0 \\
10,0\end{array}$ \\
\hline Pendidikan & & & & \\
\hline $\begin{array}{ll}- & \text { Tidak Iulus SD } \\
- & \text { Lulus SD } \\
- & \text { Lulus SMP } \\
- & \text { Lulus SMA } \\
- & \text { Lulus akademik } \\
- & \text { S1/S2/S3 }\end{array}$ & $\begin{array}{r}1 \\
1 \\
0 \\
16 \\
7 \\
5\end{array}$ & $\begin{array}{r}3,3 \\
3,3 \\
0,0 \\
53,3 \\
23,3 \\
16,7\end{array}$ & $\begin{array}{r}3 \\
5 \\
6 \\
14 \\
1 \\
1\end{array}$ & $\begin{array}{r}10,0 \\
16,7 \\
20,0 \\
46,7 \\
3,3 \\
3,3\end{array}$ \\
\hline
\end{tabular}




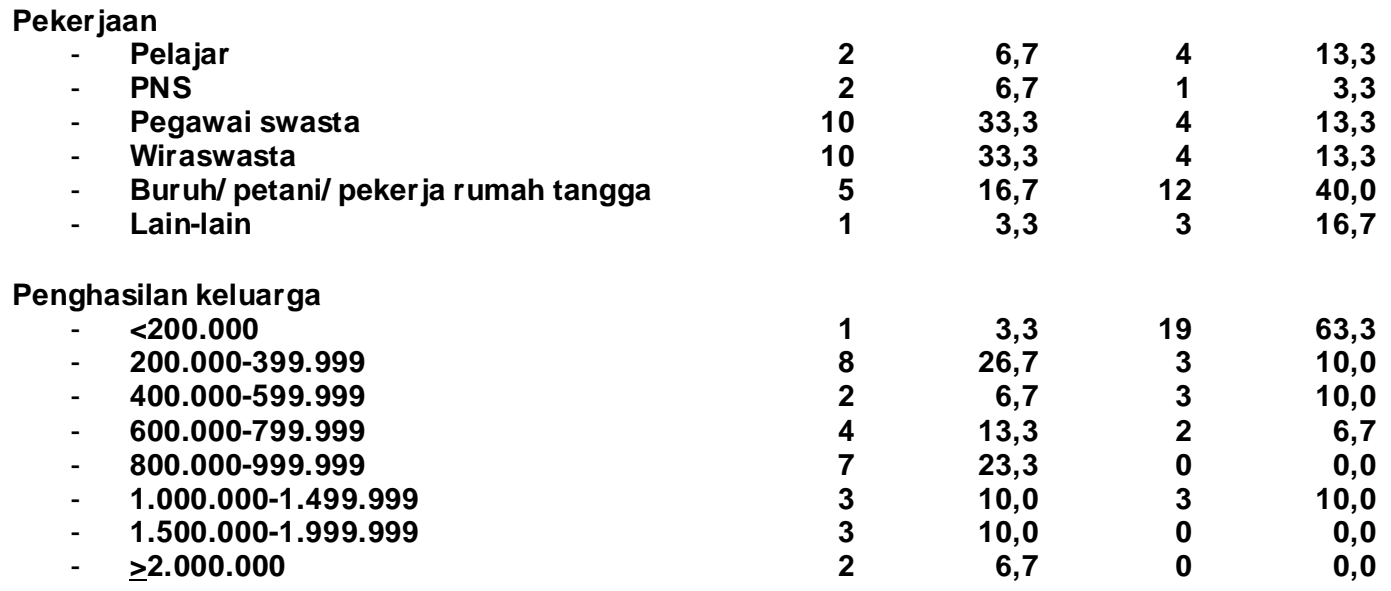

Sumber: hasil Olah Data

Dari penelitian ini didapatkan karakteristik responden yang bervariasi, untuk jenis kelamin pasien, jenis kelamin laki-laki mendominasi baik pada responden rawat inap maupun IGD yaitu 60 persen untuk rawat inap dan 56,7 persen untuk IGD. Sedangkan untuk usia responden, usia 25-65 (dewasa muda) mendominasi usia responden untuk rawat inap maupun IGD, yaitu 60 persen untuk rawat inap dan 76,7 persen untuk IGD.

Distibusi tingkat pendidikan responden bervariasi dengan kelompok terbanyak adalah responden dengan tingkat pendidikan lulus SMA yaitu sebanyak 46,7 persen untuk responden rawat inap, dan 53,3 persen untuk responden IGD. Untuk pekerjaan responden juga didapatkan hasil distribusi yang bervariasi, untuk responden rawat inap, kelompok terbesar yaitu responden dengan pekerjaan buruh/tani/pekerja rumah tangga, yaitu sebesar $\mathbf{4 0}$ persen.Distribusi penghasilan responden kelompok terbanyak untuk rawat inap adalah kelompok dengan penghasilan < Rp. 200.000, yaitu sebanyak 63,3 persen. Untuk pasien IGD kelompok terbesar yaitu responden dengan penghasilan $R p$. 200.000,- s/d Rp. 399.999,-- sebanyak 26,7 persen. 
Kepuasan Pelanggan

Dari diagram dibawah kita dapat melihat bahwa sebagian besar (70\%) digunakan sebagai alat untuk; 1) evaluasi kualitas pelayanan, 2) evaluasi terhadap konsultasi intervensi dan hubungan

Gambar 1. Diagram Kepuasan Pasien Rawat Inap dan IGD di RS PKU Muhammadiyah Bantul

kepuasan pasien Ranap

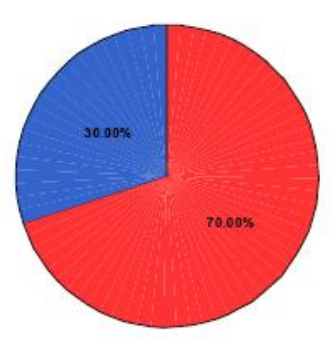



Ples show counts kepuasan pasien IGD

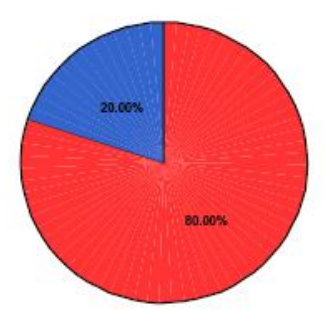

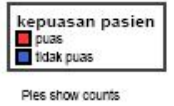

pasien rawat inap menyatakan puas terhadap pelayanan yang telah diberikan oleh RS PKU Muhammadiyah Bantul. Namun masih terdapat sebagian kecil $(30 \%)$ pasien yang merasakan tidak puas terhadap pelayanan yang telah diberikan. Sama halnya dengan pasien rawat inap, sebagian besar $(80 \%)$ pasien IGD juga merasa puas terhadap pelayanan yang telah mereka terima. Sedangkan 20 persennya merasa tidak puas terhadap pelayanan yang telah diberikan.

Hal ini sangatlah mungkin terjadi, karena terdapat berbagai faktor yang dapat mempengaruhi kepuasan mereka. Maka untuk itu sangatlah penting bagi sebuah rumah sakit untuk menganalisa tingkat kepuasan pasien mereka. Analisa terhadap kepuasan pasien akan sangat bermanfaat sekali bagi sebuah rumah sakit. Merkouris, et al menyatakan bahwa mengukur kepuasan pasien dapat antara perilaku sehat dan sakit, 3) membuat keputusan administrasi, 4) evaluasi efek dari perubahan organisasi pelayanan, 5) administrasi staff, 6) fungsi pemasaran, 7) formasi etik professional5,6,7.

Kita dapat menyimpulkan bahwa, RS PKU Muhammadiyah Bantul telah memberikan pelayanan yang cukup berkualitas sehingga sebagian besar dari pasien merasakan puas terhadap pelayanan yang telah mereka berikan. Namun, pihak rumah sakit juga harus mengevaluasi lagi, karena masih terdapat sebagian kecil pasien yang merasa tidak puas terhadap pelayanan yang telah mereka berikan. Hendaknya pelayanan yang diberikan lebih ditingkatkan lagi kua litasnya.

Hubungan Karakteristik Responden dengan Kepuasan Responden 
Dengan menggunakan analisis Chi-Square didapatkan hasil bahwa untuk responden Rawat Inap tidak terdapat hubungan yang bermakna antara karakteristik responden dengan
Dari hasil diatas didapatkan bahwa responden dengan tingkat pendidikan lebih rendah akan merasa lebih puas. Tingkat pendidikan seseorang akan cenderung membantunya untuk

Tabel 2. Hubungan Karakteristik dengan Kepuasan Responden Rawat Inap RS PKU Muhammadiyah Bantul

\begin{tabular}{|c|c|c|c|c|c|c|}
\hline \multirow[t]{2}{*}{ Karakteristik } & \multicolumn{2}{|c|}{ Puas } & \multicolumn{2}{|c|}{ Tidak puas } & \multirow[t]{2}{*}{$\mathrm{X}^{2}$} & \multirow[t]{2}{*}{ OR } \\
\hline & $\mathrm{n}$ & $\%$ & $\mathrm{n}$ & $\%$ & & \\
\hline Jenis Kelamin: & & & & & $1,29(\mathrm{p}=0,26)$ & $2,5(0,51-12,35)$ \\
\hline - laki-laki & 14 & 66,7 & 4 & 44,4 & & \\
\hline - perempuan & 7 & 33,3 & 5 & 55,6 & & \\
\hline Umur & & & & & $0,37(\mathrm{p}=0,54)$ & $0,6(0,93-3,81)$ \\
\hline$-18-25$ tahun & 7 & 33,3 & 2 & 22,2 & & \\
\hline$->25$ tahun & 14 & 66,7 & 7 & 77,8 & & \\
\hline Pendidikan & & & & & $0,41(\mathrm{p}=0,52)$ & $2,5(0,14-45,01)$ \\
\hline$-\leq \mathrm{SMA}$ & 20 & 95,2 & 8 & 88,9 & & \\
\hline$->\mathrm{SMA}$ & 1 & 4,8 & 1 & 11,1 & & \\
\hline Penghasilan & & & & & $2,13(\mathrm{p}=0,14)$ & $5,7(0,45-73,19)$ \\
\hline$-\leq$ Rp. $799.999_{3}-$ & 20 & 95,2 & 7 & 77,8 & & \\
\hline - >Rp.799.999,- & 1 & 4,8 & 2 & 22,2 & & \\
\hline
\end{tabular}

kepuasan responden $(p>0.05)$. Responden laki-laki akan cenderung 2,5 kali lebih puas dari pada responden perempuan. Dari segi umur, responden dengan usia 18-25 tahun akan merasa puas 0,6 kali dibanding dengan responden yang berusia lebih dari 25 tahun. Responden dengan tingkat pendidikan kurang dari atau sama dengan SMA akan merasa puas 2,5 kali dibandingkan dengan responden yang berpendidikan lebih dari SMA. Responden dengan penghasilan kurang dari atau sama dengan Rp. 799.999,akan merasa puas 5,7 kali dibandingkan dengan responden dengan penghasilan lebih dari Rp. 799.999,-. Tetapi semuanya itu tidak bermakna secara statistik. membentuk suatu pengetahuan sikap dan perilakunya terhadap sesuatu. Dengan pengetahuan yang baik seseorang dapat melakukan evaluasi berkaitan dengan kemampuan untuk melakukan justifikasi atau penilaian terhadap suatu materi atau objek yang ditentukan ${ }^{8}$. Semakin tinggi tingkat pendidikan seseorang, maka daya untuk mengkritisi segala sesuatu akan meningkat. Sehingga seseorang dengan pendidikan yang lebih tinggi semestinya akan lebih kritis dalam menentukan apakah pelayanan yang telah diberikan dapat memberikan rasa puas atau tidak. peningkatan ketidakpuasan pasien terhadap layanan dokter atau rumah sakit atau tenaga kesehatan lainnya dapat terjadi sebagai akibat dari semakin 
Tabel 3. Hubungan Karakteristik Responden dengan Kepuasan Responden IGD RS PKU Muhammadiyah B antul

Sumber : Hasil olah data

\begin{tabular}{|c|c|c|c|c|c|c|}
\hline \multirow[t]{2}{*}{ Karakteristik } & \multicolumn{2}{|c|}{ Puas } & \multicolumn{2}{|c|}{ Tidak puas } & \multirow[t]{2}{*}{$\mathrm{X}^{2}$} & \multirow[t]{2}{*}{ OR } \\
\hline & $\mathrm{n}$ & $\%$ & $\mathrm{n}$ & $\%$ & & \\
\hline Jenis Kelamin: & & & & & $0,71(\mathrm{p}=0,14)$ & $1,4(0,22-8,42)$ \\
\hline - laki-laki & 14 & 58,3 & 3 & 50 & & \\
\hline - perempuan & 10 & 41,7 & 3 & 50 & & \\
\hline Umur & & & & & $0,52(\mathrm{p}=0,42)$ & $0,5(0,07-3,75)$ \\
\hline - $\quad 18-25$ tahun & 5 & 20,8 & 2 & 33,3 & & \\
\hline$-\quad>25$ tahun & 19 & 79,2 & 4 & 66,7 & & \\
\hline Pendidikan & & & & & $0,19(\mathrm{p}=1,70)$ & $0,2(0,02-2,34)$ \\
\hline$-\leq \mathrm{SMA}$ & 13 & 54,2 & 5 & 83,3 & & \\
\hline$->\mathrm{SMA}$ & 11 & 45,8 & 1 & 16,7 & & \\
\hline Penghasilan & & & & & $0,36(\mathrm{p}=0,83)$ & $0,4(0,07-2,77)$ \\
\hline$-\leq$ Rp. $799.999,-$ & 11 & 45,8 & 4 & 66,7 & & \\
\hline - > Ro. 799.999 & 13 & 54.2 & 2 & 33.3 & & \\
\hline
\end{tabular}

tinggi pendidikan rata-rata masyarakat sehingga membuat mereka lebih tahu tentang haknya dan lebih asertif.

Sama dengan hasil olah data responden Rawat Inap, data responden IGD juga diolah dengan menggunakan analisis Chi-Square. Didapatkan hasil bahwa untuk responden IGD tidak terdapat hubungan yang bermakna antara karakteristik responden dengan kepuasan responden ( $p>0.05)$. Responden laki-laki akan 1,4 kali lebih puas dibanding responden perempuan. Menurut usia, responden dengan usia lebih dari 18-25 tahun akan merasa puas 0,5 kali dibanding dengan responden yang berusia lebih dari 25 tahun. Responden dengan tingkat pendidikan kurang dari atau sama dengan SMA akan merasa puas 0,2 kali dibandingkan dengan responden yang berpendidikan lebih dari SMA. Responden dengan penghasilan kurang dari atau sama dengan Rp. 799.999 akan merasa puas 0,4 kali dibandingkan dengan responden dengan penghasilan lebih dari Rp. 799.999.

Hasil penelitian ini menunjukkan bahwa untuk responden rawat inap,responden dengan jenis kelamin laki-laki, responden dengan usia lebih dari 25 tahun, responden dengan pendidikan lebih rendah atau SMA, dan responden dengan penghasilan 799.999 rupiah atau kurang, akan cenderung puas terhadap pelayanan Rumah Sakit. Sedangkan untuk responden IGD, responden dengan jenis kelamin laki-laki, responden dengan usia lebih dari 25 tahun, kemudian responden dengan pendidikan lebih dari SMA, dan responden dengan penghasilan lebih dari Rp. 799.999,-- akan cenderung lebih puas terhadap pelayanan Rumah Sakit. Meskipun hal tersebut tidak bermakna secara statistik.

Hasil penelitian ini sama dengan hasil penelitian Notosutardjo (1999) yang menunjukkan bahwa tidak terdapat hubungan yang signifikan antara usia, 
jenis kelamin, pendidikan, penghasilan dan juga penghasilan pasien terhadap kepuasan. Teori pembentukan sikap juga menyatakan bahwa antara jenis kelamin laki-laki dan perempuan tidak ada perbedaan yang nyata dalam hal kemampuan memecahkan masalah, menganalisis, memimpin, memotivasi, kepemimpinan, kemampuan, belajar, kemampuan sosial, produktivitas dan kemampuan kerja9.

\section{Faktor Penentu Kepuasan}

\section{A. Tangibel}

Dari faktor tangibel untuk responden rawat inap terdapat 11 indikator, dari hasil pengolahan data, didapatkan hasil bahwa frekuensi terbanyak $(63,33 \%)$ responden mengganggap bahwa kondisi ruang rawat inap yang nyaman, bersih dan rapi dan juga kelengkapan peralatan medis yang tidak mengharuskan mereka dirujuk kerumah sakit lain "sangat penting" dalam menentukan kepuasan mereka. Kemudian setelah itu indikator yang dianggap sangat penting oleh responden adalah penerangan lampu pada ruang perawatan dan halaman ruang rawat inap di waktu malam dan juga kelengkapan perabot di ruang rawat inap "sangatlah penting", yaitu masing-masing sebesar 56,7 persen. Secara keseluruhan, sebagian besar responden (50\%) menganggap faktor tangible "Penting" dalam menentukan tingkat kepuasan mereka.

Faktor tangible untuk IGD memiliki

Tabel 4. Distribusi Frekuensi Tingkat Kepentingan Faktor Tangible Rawat Inap Sumber : Data diolah

\begin{tabular}{|c|c|c|c|c|c|c|}
\hline No & Indikator & $\operatorname{STP}(\%)$ & $\mathrm{TP}(\%)$ & $\mathrm{RR}(\%)$ & $\mathrm{P}(\%)$ & $\mathrm{SP}(\%)$ \\
\hline 1 & $\begin{array}{l}\text { Kondisi ruang rawat inap yang nyaman, bersih } \\
\text { dan rapi }\end{array}$ & 0 & 0 & 3,3 & 33,3 & 63,33 \\
\hline 2 & $\begin{array}{l}\text { Penampilan dokter dan perawat yang bersih dan } \\
\text { rapi }\end{array}$ & 0 & 0 & 3,3 & 50,0 & 46,7 \\
\hline 3 & $\begin{array}{l}\text { Penerangan lampu pada ruang perawatan dan } \\
\text { halaman ruang rawat inap di waktu malam }\end{array}$ & 0 & 0 & 3,3 & 40,0 & 56,7 \\
\hline 4 & Kelengkapan perabotan di ruang rawat inap & 0 & 0 & 6,7 & 36,7 & 56,7 \\
\hline 5 & Ruang rawat inap bebas dari serangga & 0 & 0 & 0 & 50 & 50 \\
\hline 6 & Makanan menarik & 0 & 10 & 6,7 & 66,7 & 16,7 \\
\hline 7 & Tempat makanan (sendok, piring,gelas) & 0 & 3,3 & 10 & 60 & 26,7 \\
\hline 8 & Variasi menu makanan & 0 & 0 & 6,7 & 53,3 & 40 \\
\hline 9 & $\begin{array}{l}\text { Kelengkapan perawatan medis sehingga tidak } \\
\text { perlu dikirim ke rumah sakit lain untuk } \\
\text { melakukan pemeriksaan tertentu. }\end{array}$ & 0 & 0 & 3,3 & 33,3 & 63,3 \\
\hline 10 & Tersedianya tempat parkir yang cukup & 0 & 0 & 6,7 & 56,7 & 36,7 \\
\hline 11 & $\begin{array}{l}\text { Tersedianya tempat untuk keluarga penunggu } \\
\text { pasien }\end{array}$ & 0 & 0 & 6,7 & 70 & 23,3 \\
\hline & Jumlah & & 13,3 & 56,7 & 550 & 480.13 \\
\hline & Rata-rata & & 1,21 & 5,16 & 50 & 43,65 \\
\hline
\end{tabular}


Tabel 5. Distribusi Frekuensi Tingkat Kepentingan Faktor Tangibel IGD

\begin{tabular}{|c|c|c|c|c|c|c|}
\hline No & Indikator & $\operatorname{STP}(\%)$ & $\mathrm{TP}(\%)$ & $\mathrm{RR}(\%)$ & $\mathrm{P}(\%)$ & $\mathrm{SP}(\%)$ \\
\hline 1 & $\begin{array}{l}\text { Kondisi ruang IGD yang nyaman, bersih dan } \\
\text { rapi. }\end{array}$ & 0 & 0 & 6,7 & 36,7 & 56,7 \\
\hline 2 & $\begin{array}{l}\text { Penampilan dokter dan perawat yang bersih } \\
\text { dan rapi }\end{array}$ & 3,3 & 0 & 3,3 & 36,7 & 56,7 \\
\hline 3 & Penerangan lampu pada ruang IGD & 0 & 0 & 10 & 30 & 60 \\
\hline 4 & Kelengkapan perabotan untuk IGD & 0 & 0 & 6,7 & 30 & 63,3 \\
\hline 5 & Ruang IGD bebas dari serangga & 0 & 0 & 10 & 30 & 60 \\
\hline 6 & $\begin{array}{l}\text { Kelengkapan perawatan medis sehingga } \\
\text { tidak perlu dikirim ke rumah sakit lain untuk } \\
\text { melakukan pemeriksaan tertentu. }\end{array}$ & 0 & 0 & 16,7 & 23,3 & 60 \\
\hline 7 & Tersedianya tempat parkir yang cukup & 3,3 & 0 & 16,7 & 50 & 30 \\
\hline & Jumlah & 6,6 & 0 & 53,4 & 236,7 & 386,7 \\
\hline & Rata-rata & 0,94 & 0 & 7,63 & 33,81 & 55,24 \\
\hline
\end{tabular}

Sumber: Hasil Olah Data

tujuh indikator, sebagian besar responden menyatakan indikatorindikator tersebut "Sangat Penting", kecuali untuk indikator ketujuh, responden sebagian besar (50\%) menganggap indikator tersebut "Penting". Tetapi terdapat sebagian kecil $(3,3 \%)$ responden menyatakan bahwa indikator kedua dan ketujuh "Sangat Tidak Penting". Secara keseluruhan, rata-rata sebagian besar (55,24\%) responden menyatakan faktor tangibel "sangat Penting".

Dari hasil pengolahan data dapat kita lihat bahwa untuk responden rawat inap, kondisi ruangan rawat inap yang bersih, nyaman dan rapi mendapat persentase paling banyak tingkat kepentingannya dalam menentukan kepuasan responden. Hal ini sangatlah wajar, karena apabila terdapat pasien pertama kali masuk ke sebuah rumah sakit, maka yang pertama kali mereka perhatikan adalah kondisi ruang sekitar mereka, bagaimana kondisi ruangan tersebut, apakah bersih, nyaman, dan juga rapi. Sehingga pihak rumah sakit hendaknya memperhatikan kondisi kebersihan, kenyamanan, dan juga kerapian ruangan tersebut, hal ini tidak hanya berlaku untuk ruang rawat inap saja, tetapi juga kondisi sekitar ruang rawat inap hendaknya selalu dijaga kebersihan dan kerapiannya sehingga pasien dapat merasa nyaman berada di lingkungan terse but.

Berbeda dengan responden rawat inap, bagi responden IGD, indikator faktor tangibel yang mereka anggap paling penting adalah perabotan untuk IGD. Namun demikian, kebersihan di ruang IGD hendaknya juga selalu diperhatikan. Terlebih lagi RS PKU Muhammadiyah Bantul adalah rumah sakit Islam, dan Islam sendiri mengajarkan kebersihan kepada 
umatnya, hal ini seperti terdapat dalam hadits riwayat Tirmidzi yang berbunyi "Sesungguhnya Allah itu baik, Dia suka kepada yang baik, Dia juga bersih, suka kepada yang bersih...". Maka sebaiknya RS PKU Muhammadiyah Bantul hendaknya selalu menjaga kebersihan lingkungannya, selain untuk meningkatkan kepuasan pasien juga untuk memberikan tauladan, bahwa islam itu bersih, mengajarkan tentang kebersihan, dan c inta akan kebersihan.

\section{B. Reliability}

Untuk rawat inap, faktor reliability memiliki tiga indikator. Hasil pengolahan data menunjukkan bahwa ketiga indikator tersebut dipandang "Sangat menganggap ketiga indikator dari faktor reliability adalah "Sangat Penting" $(56,67 \%)$. Untuk indikator yang pertama, kesigapan dokter untuk melakukan pertolongan pertama di ruang IGD, 70 persen responden menyatakan indikator tersebut "sangat Penting", sedangkan 23,3 persen responden menyatakan indikator tersebut "Penting", dan 6,7 persen lainnya menganggap bahwa indikator tersebut tidak begitu penting ("rata-rata").

Dari hasil dibawah dapat kita lihat bahwa responden rawat inap menilai bahwa indikator yang sangat penting dari faktor reliability yaitu kesesuaian pemberian obat dengan jadwalnya, karena ketepatan pemberian obat akan

Tabel 6. Distribusi Frekuensi Tingkat Kepentingan Faktor Reliability Rawat Inap

\begin{tabular}{|c|c|c|c|c|c|c|}
\hline \multirow[t]{2}{*}{ No } & \multirow[t]{2}{*}{ Indikator } & \multirow[t]{2}{*}{$\mathrm{STP}(\%)$} & $\mathrm{TP}(\%)$ & \multicolumn{2}{|c|}{$\mathrm{RR}(\%)$} & $\mathrm{SP}(\%)$ \\
\hline & & & \multicolumn{4}{|c|}{$\mathrm{P}(\%)$} \\
\hline 1 & $\begin{array}{l}\text { Waktu periksa dokter di bangsal sesuai } \\
\text { dengan jadwal }\end{array}$ & 0 & 0 & 13,3 & 30 & 56,7 \\
\hline 2 & $\begin{array}{l}\text { Kecepatan perawat menanggapi panggilan } \\
\text { bel pasien }\end{array}$ & 0 & 0 & 6,7 & 33,3 & 60 \\
\hline 3 & $\begin{array}{l}\text { Kesesuaian pemberian obat dengan } \\
\text { jadwalnya }\end{array}$ & 0 & 0 & 6.7 & 30 & 63,3 \\
\hline & Jumlah & & & 26,7 & 93,3 & 180 \\
\hline & Rata-rata & & & 8,9 & 31,1 & 60 \\
\hline
\end{tabular}

Sumber: Hasil Olah Data

Penting" dalam menentukan tingkat kepuasan mereka. Namun diantara ketiga indikator tersebut prosentase terbesar adalah indikator ketiga, kesesuaian pemberian obat dengan jadwalnya, yaitu sebesar 63,3 persen.

mempengaruhi hasil dari proses terapi untuk pasien tersebut, apabila pasien mendapatkan obat sesuai dengan jadwalnya, tentu saja out put dari terapi yang diberikan untuk pasien tersebut

Table 7. Distribusi Frekuensi Tingkat Kepentingan Faktor Reliability IGD

\begin{tabular}{llrrrrr}
\hline No & \multicolumn{1}{c}{ Indikator } & STP(\%) & TP(\%) & $\mathrm{RR}(\%)$ & $\mathrm{P}(\%)$ & $\mathrm{SP}(\%)$ \\
\hline 1 & Kesigapan dokter untuk melakukan & 0 & 0 & 6,7 & 23,3 & 70 \\
& $\begin{array}{l}\text { pertolongan pertama di ruang IGD } \\
2\end{array}$ & & & & & \\
& $\begin{array}{l}\text { Kecepatan perawat IGD melakukan } \\
\text { playanan di IGD }\end{array}$ & 0 & 0 & 3,3 & 40 & 56,7 \\
3 & Kecepatan pemeriksaan tambahan untuk & 0 & 0 & 13,3 & 43,3 & 43,3
\end{tabular}


terapi yang baik dan sembuh dari penyakit yang mereka derita, tentu saja mereka akan merasa puas dengan pelayanan yang telah mereka dapatkan. responden IGD. Faktor reliabilitas menjadi faktor yang dianggap paling penting oleh responden, tentu saja karena faktor reliability atau keandalan,

Tabel 8. Distribusi Frekuensi Tingkat Kepentingan Faktor Respon-siveness Rawat Inap

\begin{tabular}{|c|c|c|c|c|c|c|}
\hline No & Indikator & STP(\%) & $\mathrm{TP}(\%)$ & $\mathrm{RR}(\%)$ & $\mathrm{P}(\%)$ & $\mathrm{SP}(\%)$ \\
\hline 1 & $\begin{array}{l}\text { Sikap perilaku dokter saat melakulkan } \\
\text { pemeriksaan rutin }\end{array}$ & 0 & 3,3 & 6,7 & 40 & 50 \\
\hline 2 & $\begin{array}{l}\text { Pelayanan petugas ruang rawat inap yang } \\
\text { sopan dan ramah }\end{array}$ & 0 & 0 & 6,7 & 33,3 & 60 \\
\hline 3 & $\begin{array}{l}\text { Sikap dan perilaku petugas pada saat } \\
\text { memberikan pelayanan di fasilitas } \\
\text { penunjang medis }\end{array}$ & 0 & 3,3 & 13,3 & 43,3 & 40 \\
\hline 4 & $\begin{array}{l}\text { Sikap dan perilaku petugas yang } \\
\text { menghicangkan makanan. }\end{array}$ & 0 & 3,3 & 16,7 & 46,7 & 33,3 \\
\hline & Jumlah & 0 & 9,9 & 43,3 & 163,3 & 183,3 \\
\hline & Rata-rata & 0 & 2,48 & 10,86 & 40,86 & 45,86 \\
\hline
\end{tabular}

Sumber: Hasil Olah Data

Sedangkan untuk responden IGD, indikator yang mereka anggap sangat penting dan mendapat persentase tertinggi yaitu kesigapan dokter untuk melakukan pertolongan pertama di ruang IGD, karena untuk pasien IGD, mereka membutuhkan pertolongan yang cepat, sehingga kesigapan dokter sangat diperlukan disini. Apabila dokter sigap dalam menangani pasien, maka pasien akan dapat segera terhindar dari keadaan yang mengancam jiwa mereka, apabila dokter dapat mengatasi keadaan tersebut dengan sigap, maka pasien akan merasa puas karena telah mendapatkan pertolongan yang semestinya mereka dapatkan.

Apabila dilihat secara keseluruhan, faktor reliability ini merupakan faktor yang dianggap paling penting diantara faktor lainnya, baik untuk responden rawat inap maupun mencakup kemampuan provider kesehatan untuk memberikan pelayanan yang dijanjikan dengan segera, akurat dan memuaskan. Apabila pasien mendapatkan pelayanan dengan segera dan akurat sesuai dengan yang mereka inginkan, maka secara otomatis pasien akan merasakan kepuasan atas pelayanan yang telah mereka dapatkan terlebih lagi bagi pasien IGD, kecepatan dan juga penanganan yang akurat sangat dibutuhkan oleh mereka, semakin cepat dan tepat penanganan yang diberikan, maka pasien akan merasa semakin puas.

\section{Responsiveness}

Dari faktor responsiveness terdapat empat indikator penentu kepuasan pasien, dari data yang didapat, didapatkan distribusi terbesar responden menyatakan indikator tersebut "Sangat Penting" adalah pada indikator kedua 
$(60 \%)$, yaitu pelayanan petugas rawat inap yang sopan dan ramah. Setelah itu diikuti indikator pertama, sikap perilaku dokter saat melakukan pemeriksaan rutin, $\mathbf{5 0}$ persen responden menyatakan indikator tersebut "Sangat Penting", sedangkan 40 persen menyatakan "Penting" dan 6,6 persen menyatakan "Rata-rata" namun terdapat 3,3 persen responden menyatakan bahwa indikator pertama ini tidaklah penting dalam menentukan tingkat kepuasan mereka. Demikian pula untuk indikator ketiga dan keempat, terdapat 3,3 persen responden yang menyatakan bahwa indicator tersebut tidaklah penting dalam menentukan tingkat kepuasan mereka. Secara keseluruhan, responden menganggap faktor responsiveness "Sangat Penting" (45,825\%) dalam mentukan tingkat kepuasan mereka. Sama dengan rawat inap, responden IG D juga secara keseluruhan memandang faktor Responsiveness "Sangat Penting".

Dari faktor ini baik untuk responden rawat inap maupun IGD memandang bahwa sikap dan perilaku dokter mereka pandang sangat penting dalam menentukan kepuasan mereka. Hal ini dikarenakan pasien akan berhadapan langsung dan lebih lama dengan dokter dan perawat dibandingkan dengan pemberi pelayanan lainnya, sehingga kontak dengan dokter dan perawat yang nyaman akan mempengaruhi kepuasan mereka, apabila dokter dan perawat memberikan pelayanan dengan baik dan ramah maka pasien akan merasa puas dengan pelayanan yang mereka dapatkan.

\section{Assurance}

Untuk pasien rawat inap, faktor assurance memiliki 9 indikator dalam menentukan tingkat kepuasan pasien. Sebagian besar responden menyatakan indikator-indikator tersebut "Sangat Penting" dalam menentukan tingkat kepuasan mereka, kecuali untuk indikator yang keempat dan kesembilan, untuk indikator keempat, sebagian besar responden $(56,7 \%)$ menyatakan indikator tersebut "Penting" dan 30 persen menyatakan "Sangat Penting", sisanya(13,3\%) menganggap indikator tersebut tidak begitu penting ("rata-

Tabel 10. Distribusi Frekuensi Tingkat Kepentingan Faktor Assurance Rawat Inap (Sumber : Hasil Olah Data)

\begin{tabular}{|c|c|c|c|c|c|c|}
\hline No & Indikator & $\operatorname{STP}(\%)$ & $\mathrm{TP}(\%)$ & $\operatorname{RR}(\%)$ & $\mathrm{P}(\%)$ & $\mathrm{SP}(\%)$ \\
\hline 1 & $\begin{array}{l}\text { Kesungguhan dokter dalam menangani } \\
\text { penyakit pasien. }\end{array}$ & 0 & 0 & 0 & 30 & 70 \\
\hline 2 & Ketelitian dokter dalam memeriksa pasien & 0 & 0 & 3,3 & 13,3 & 83,3 \\
\hline 3 & $\begin{array}{l}\text { Dokter menjelaskan pengobatan yang akan } \\
\text { dilakukan }\end{array}$ & 0 & 0 & 3,3 & 40 & 56,7 \\
\hline 4 & Kemanjuran terapi yang diberikan dokter & 0 & 0 & 13,3 & 56,7 & 30 \\
\hline 5 & $\begin{array}{l}\text { Penjelasan dokter tentang makanan yang } \\
\text { harus dipantang }\end{array}$ & 0 & 0 & 0 & 43,3 & 56,7 \\
\hline 6 & $\begin{array}{l}\text { Tanggapan dan jawaban dokter atas keluhan } \\
\text { pasien }\end{array}$ & 0 & 0 & 6,7 & 40 & 53,3 \\
\hline 7 & Pengalaman dokter & 0 & 0 & 0 & 40 & 60 \\
\hline 8 & $\begin{array}{l}\text { Keterampilan perawat dalam memberikan } \\
\text { pelayanan medis ke pasien }\end{array}$ & 0 & 0 & 0 & 40 & 60 \\
\hline 9 & $\begin{array}{l}\text { Keterampilan petugas medis lain dalam } \\
\text { memberikan pelayanan kesehatan }\end{array}$ & 0 & 0 & 3,3 & 53,3 & 43,3 \\
\hline & Jumlah & 0 & 0 & 29,9 & 473,6 & 513,3 \\
\hline & Rata_rata & $n$ & n & 222 & 596 & $57 n 3$ \\
\hline
\end{tabular}


rata"). Sedangkan untuk indikator kesembilan, sebagian besar responden $(53,3 \%)$ menyatakan indikator tersebut "Penting" dalam menentukan tingkat kepuasan mereka, baru setelah itu, 43,3 persen diantaranya menyatakan bahwa indikator tersebut "Sangat Penting" dalam menentukan tingkat kepuasan mereka, sisanya $(3,3 \%)$ menyatakan "rata-rata". Secara keseluruhan, faktor assurance dianggap "Sangat Penting" oleh responden dalam menentukan tingkat kepuasan mereka. harus dipantang, 6,7 persen responden menyatakan indikator ini "Tidak penting".

Baik untuk responden rawat inap maupun IGD, dari hasil pengolahan data diatas dapat kita lihat bahwa ketelitian dokter dalam memeriksa pasien adalah indikator yang mereka anggap paling "Sangat Penting" dalam menentukan tingkat kepuasan mereka. Karena ketelitian dokter dalam memeriksa pasien akan berpengaruh terhadap diagnosis yang ditegakkan, apabila dokter dapat mendiagnosis penyakit yang diderita

Tabel 11. Distribusi Frekuensi Tingkat Kepentingan Faktor Assurance IGD

\begin{tabular}{|c|c|c|c|c|c|c|}
\hline No & Indikator & $\mathrm{STP}(\%)$ & $\mathrm{TP}(\%)$ & $\mathrm{RR}(\%)$ & $\mathrm{P}(\%)$ & $\mathrm{SP}(\%)$ \\
\hline 1 & $\begin{array}{l}\text { Kesungguhan dokter dalam menangani } \\
\text { penyakit pasien. }\end{array}$ & 0 & 0 & 6,7 & 36,7 & 56,7 \\
\hline 2 & Ketelitian dokter dalam memeriksa pasien & 0 & 0 & 10 & 20 & 70 \\
\hline 3 & $\begin{array}{l}\text { Kemampuan petugas membedakan kasus } \\
\text { gawat dan tidak gawat }\end{array}$ & 0 & 0 & 13,3 & 36,7 & 50 \\
\hline 4 & $\begin{array}{l}\text { Dokter menjelaskan pengobatan/tindakan } \\
\text { yang akan dilakukan }\end{array}$ & 0 & 0 & 16,7 & 46,7 & 36,7 \\
\hline 5 & Kemanjuran terapi yang diberikan dokter & 0 & 0 & 26,7 & 40 & 33,3 \\
\hline 6 & $\begin{array}{l}\text { Penjelasan dokter tentang makanan yang } \\
\text { harus dipantang }\end{array}$ & 0 & 6,7 & 10 & 50 & 33,3 \\
\hline 7 & $\begin{array}{l}\text { Tanggapan dan jawaban dokter atas keluhan } \\
\text { pasien }\end{array}$ & 0 & 0 & 6,7 & 56,7 & 36,7 \\
\hline 8 & Pengalaman dokter & 0 & 0 & 13,3 & 30 & 56,7 \\
\hline 9 & $\begin{array}{l}\text { Keterampilan perawat dalam melayani } \\
\text { pasien }\end{array}$ & 0 & 0 & 10 & 33,3 & 56,7 \\
\hline & Jumlah & 0 & 6,7 & 113,4 & 350,1 & 430,1 \\
\hline & Rata-rata & 0 & 0,74 & 12,6 & 38,9 & 47,79 \\
\hline
\end{tabular}

Dan untuk responden IGD, secara keseluruhan, faktor assurance dianggap "Sangat Penting". Untuk indikator keempat sampai dengan faktor ketujuh, responden sebagian besar menyatakan indikator-indikator tersebut "Penting", namun untuk indikator keenam, Penjelasan dokter tentang makanan yang pasien dengan tepat, dan memberikan terapi yang tepat pula, maka kondisi pasien akan berangsur membaik, dan pasienpun akan merasa puas dengan pelayanan yang mereka dapat. Sebaliknya, apabila dokter kurang teliti dalam melayani pasien, maka penanganan yang diberikan juga akan tidak maksimal, dan hal ini akan 
merugikan pasien, sehingga pasien akan merasa kurang puas dengan pelayanan yang telah diberikan.

\section{Empathy}

Dari faktor empathy terdapat dua indikator untuk rawat inap dan juga IGD, untuk rawat inap, indikator yang menyatakan indikator ini "Sangat Penting" dalam menetukan tingkat kepuasan mereka, dan 40persennya menyatakan indikator tersebut "Penting".

Untuk responden IGD, sebagian responden menyatakan bahwa faktor empathy adalah "Penting" dalam menentukan tingkat kepuasan pasien.

Tabel 12. Distribusi Frekuensi Tingkat Kepentingan Faktor E mpathy Rawat Inap

\begin{tabular}{llrrrrr}
\hline No & \multicolumn{1}{c}{ Indikator } & $\mathrm{STP}(\%)$ & $\mathrm{TP}(\%)$ & $\mathrm{RR}(\%)$ & $\mathrm{P}(\%)$ & $\mathrm{SP}(\%)$ \\
\hline 1 & Sikap perawat dan dokter menanggapi & 0 & 0 & 6,7 & 53,3 & 40 \\
& $\begin{array}{l}\text { pertanyaan keluarga pasien dan } \\
\text { pengunjung/tamu pasien }\end{array}$ & & & & & \\
2 & $\begin{array}{l}\text { Kesediaan perawat untuk menolong pasien } \\
\text { duduk, berdiri dan berjalan }\end{array}$ & 0 & 0 & 16,7 & 40 & 43 \\
& Jumlah & 0 & 0 & 23,4 & 93,3 & 83 \\
\hline & Rata-rata & 0 & 0 & 11,7 & 46,65 & 41,5 \\
\hline
\end{tabular}

Sumber: Hasil Olah Data

pertama, sikap perawat dan dokter dalam menanggapi pertanyaan keluarga pasien dan pengunjung tamu pasien, 53,3persen responden menganggap indikator ini "Penting" dalam menentukan tingkat kepuasan mereka, sedangkan 40persen dari responden mengganggap indikator
Dari faktor ini terdapat dua indikator, untuk indikator yang pertama, terdapat 3,3 persen responden yang menyatakan bahwa indikator tersebut "Tidak Penting" dalam menentukan tingkat kepuasan mereka. Dari hasil tersebut dapat kita simpulkan bahwa baik untuk responden

Tabel 13. Distribusi frekuensi tingkat kepentingan faktor E mpathy IGD

\begin{tabular}{llrrrrr}
\hline No & \multicolumn{1}{c}{ Indikator } & $\mathrm{STP}(\%)$ & $\mathrm{TP}(\%)$ & $\mathrm{RR}(\%)$ & $\mathrm{P}(\%)$ & $\mathrm{SP}(\%)$ \\
\hline 1 & Sikap perawat dan dokter terhadap keluarga & 0 & 3,3 & 20 & 40 & 36,7 \\
& $\begin{array}{l}\text { pasien } \\
2\end{array}$ & & & & & \\
& Kesediaan dokter dan perawat untuk & 0 & 0 & 16,7 & 43,3 & 40 \\
& menolong kebutuhan pasien & & & & & \\
\hline & Jumlah & 0 & 3,3 & 36,7 & 83,3 & 76,7 \\
\hline & Rata-rata & 0 & 1,65 & 18,35 & 41,65 & 38,35 \\
\hline & Sumber: Hasil Olah Data & & & & &
\end{tabular}

tersebut "Sangat Penting" Indikator kedua, kesediaan perawat untuk menolong pasien duduk, berdiri, dan berjalan, 43 persen responden rawat inap maupun IGD memandang kesediaan dokter dan perawat untuk menolong kebutuhan pasien adalah indikator yang lebih penting dari pada 
indikator yang lainnya. Empathy disini yaitu kemampuan karyawan rumah sakit untuk memberikan perhatian penuh kepada pasien dengan kemudahan dalam melakukan kontak komunikasi yang baik, memahami kebutuhan pasien dengan sopan dan peduli. Apabila pasien merasa nyaman, meskipun tidak berhubungan langsung dengan efektivitas layanan kesehatan, tetapi dapat mempengaruhi kepuasan pasien sehingga mendorong pasien untuk datang berobat kembali ke tempat tersebut ${ }^{10}$.

\section{F. Accessibility}

Untuk faktor yang terakhir ini, terdapat 5 indikator kepuasan. Untuk responden rawat inap secara dibawah, untuk indikator pertama, ruang rawat inap mudah dicari, 56,7 persen responden menganggap ini "Penting" dan 30 persen menganggap ini "Sangat Penting". Sedangkan untuk indikatorindikator lainnya (indikator kedua, ketiga, keempat dan juga kelima) sebagian besar responden menyatakan indikatorindikator tersebut "Sangat Penting".

Sama dengan responden rawat inap, responden IGD secara keseluruhan, sebagian besar responden $(52,66 \%)$ juga menyatakan bahwa faktor accessibility "Sangat Penting" dalam menentukan tingkat kepuasan mereka. Namun untuk indikator ketiga, perawat jaga mudah untuk dihubungi, sebagian besar $(50 \%)$ responden menyatakan indikator ini "Penting", dan 43,3 persen lainnya

Tabel 14. Distribusi Frekuensi Tingkat Kepentingan Faktor Accesibility Rawat Inap

\begin{tabular}{llrrrrr}
\hline No & \multicolumn{1}{c}{ Indikator } & $\mathrm{STP}(\%)$ & $\mathrm{TP}(\%)$ & $\mathrm{RR}(\%)$ & $\mathrm{P}(\%)$ & $\mathrm{SP}(\%)$ \\
\hline 1 & Ruang rawat inap mudah dicari & 0 & 0 & 13,3 & 56,7 & 30 \\
2 & Dokter perawat mudah untuk dihubungi & 0 & 0 & 6,7 & 40 & 53,3 \\
3 & Perawat mudah untuk dihubungi & 0 & 0 & 3,3 & 36,7 & 60 \\
4 & Biaya sewa ruang rawat inap terjangkau & 0 & 0 & 3,3 & 33,3 & 63,3 \\
5 & Biaya obat yang terjangkau & 0 & 0 & 3,3 & 26,7 & 70 \\
\hline & Jumlah & 0 & 0 & 29,9 & 193,4 & 276,6 \\
\hline & Rata-rata & 0 & 0 & 5,98 & 38,68 & 55,32
\end{tabular}

keseluruhan, sebagian besar reponden $(55,32 \%)$ menganggap faktor ini "Sangat Penting" dalam menentukan tingkat kepuasan mereka. Secara rinci seperti yang kita lihat dalam tabel

menyatakan indikator ini "Sangat Penting", sisanya, 6,7 persen responden menyatakan indikator ini kurang penting dalam menentukan tingkat kepuasan mereka.

Tabel 15. Distribusi Frekuensi Tingkat Kepentingan Faktor Accesibility IG D

\begin{tabular}{llrrrrr}
\hline No & \multicolumn{1}{c}{ Indikator } & $\mathrm{STP}(\%)$ & $\mathrm{TP}(\%)$ & $\mathrm{RR}(\%)$ & $\mathrm{P}(\%)$ & $\mathrm{SP}(\%)$ \\
\hline 1 & IGD mudah dicari & 0 & 0 & 6,7 & 33,3 & 60 \\
2 & Dokter IGD mudah untuk dihubungi & 0 & 0 & 6,7 & 40 & 53,3 \\
3 & Perawat jaga mudah untuk dihubungi & 0 & 0 & 6,7 & 50 & 43,3 \\
4 & Biaya Perawatan di IGD terjangkau & 0 & 0 & 16,7 & 33,3 & 50 \\
5 & Biaya obat terjangkau & 0 & 3,3 & 16,7 & 23,3 & 56,7 \\
\hline & Jumlah & 0 & 3,3 & 53,5 & 179,9 & 263,3 \\
\hline & Rata-ratal & 0 & 0,66 & 10,7 & 35,98 & 52,66
\end{tabular}


Terdapat beberapa pasien yang menganggap salah satu dari indikator tersebut tidak penting, yaitu untuk indikator kelima, yaitu tentang keterjangkauan biaya. Sebagian responden menyatakan bahwa indikator tersebut "Tidak Penting" (3,3\%). Ruang rawat inap yang mudah dicari menjadi faktor yang terpenting bagi responden IGD, karena bagi pasien gawat darurat, keterjangkauan IGD sangatlah penting, karena pasien gawat darurat memerlukan pertolongan yang cepat. Sehingga faktor pertama yang mereka perhatikan adalah lokasi pelayanan kesehatan yang paling mudah dan cepat dijangkau.

Untuk responden rawat inap, indikator yang mereka anggap paling "Sangat Penting" yaitu keterjangkauan dalam biaya obat. Untuk responden IGD, indikator ini juga merupakan indikator terpenting kedua setelah kemudahan dalam mencari IGD. Biaya menjadi indikator yang penting untuk pasien karena banyak faktor yang berpengaruh dalam hal pembiayaan ini, seperti karakteristik pasien meisalnya. Tentu saja pasien dengan penghasilan yang lebih tinggi akan lebih mudah dalam hal pembiayaan dibandingkan dengan pasien yang berpenghasilan lebih rendah. Hal lain yang dapat mempengaruhi dalam hal pembiayaan adalah ada tidaknya asuransi kesehatan untuk pasien tersebut. Pasien dengan asuransi kesehatan akan lebih mudah dalam pembiayaan, sedangkan untuk pasien tanpa asuransi kesehatan tentu akan berfikir terlebih dahulu untuk pembiayaan obat.

Kesimpulan
Sebagian besar pasien RS PKU Muhammadiyah Bantul baik pasien rawat inap maupun IGD merasa puas dengan pelayanan yang telah mereka terima. Faktor penentu tingkat kepuasan yang paling penting dalam menentukan tingkat kepuasan responden rawat inap dan IGD adalah faktor reliability. Faktor penentu tingkat kepuasan pasien untuk rawat inap diurutkan dari yang paling penting adalah, reliability, assurance, accesibility, responsiveness, tangible, dan terakhir empathy. Faktor penentu tingkat kepuasan pasien untuk IGD diurutkan dari yang paling penting adalah, reliability, tangible, responsiveness, accesibility, assurance, dan terakhir, empathy.

Untuk responden Rawat Inap, jenis kelamin laki-laki, umur lebih dari 25 tahun, pendidikan lebih rendah atau SMA, dan penghasilan Rp.799.999,- atau kurang, cenderung puas terhadap pelayanan Rumah Sakit, tetapi hal tersebut tidak bermakna secara statistik. Untuk Responden IGD, jenis kelamin lakilaki, umur lebih dari 25 tahun, pendidikan lebih tinggi dari SMA, dan penghasilan lebih dari Rp. 799.999,- cenderung puas terhadap pelayanan Rumah Sakit, tetapi hal tersebut juga tidak bermakna secara statistik.

Diharapkan pihak manajemen RS PKU Muhammadiyah Bantul dapat lebih memperhatikan faktor-faktor yang pasien anggap paling penting dalam menentukan kepuasan pasien, dan juga meningkatkan kualitas pelayanan, terutama pada faktor-faktor yang pasien anggap paling penting dalam menentukan kepuasan mereka.

DAFTAR PUSTAKA 
1. Lamri. Pengaruh Kualitas Pelayanan Terhadap Kepuasan, Minat Perilaku Penderita Rawat Inap Di Rumah Sakit Islam Samarinda. Tesis, J urusan IImuIlmu Kesehatan Program Pascasarjana. Universitas Gadjah Mada.1997.

2. Suryawati,C., Dharminto, Shaluhiyah,Z., Penyusunan Indikator Kepuasan Pasien Rawat Inap Rumah Sakit Di Provinsi J awa Tengah. J MPK 2006:177-184.

3. Nurochman. Analisa Kepuasan Pasien Terhadap Pelayanan Rawat Inap Rumah Sakit Umum Wangaya Denpasar, Tesis, J urusan IImu-ilmu Kesehatan Program Pascasarjana, Universitas Gadjah Mada.1998.

4. Arikunto. Prosedur Penelitian Suatu Pendekatan Praktik, PT Rineka Cipta: J akarta. 2006.

5. Aritonang, L.R. Kepuasan Pelanggan, PT Gramedia Pustaka Utama: J akarta. 2005
6. Irawan, H. 10 Prinsip Kepuasan Pelanggan, PT Elex Media Komputindo: J akarta. 2007

7. Levin, $R, 2005$. Measuring Patien Satisfaction. http//: www.ada/org/goto/jada ,vol.136

8. Prastanika, D.Tingkat Kepuasan Pasien Pada Pelayanan Kesehatan di Tempat Praktek Dokter Swasta di Kabupaten Kulon Progo, Karya Tulis IImiah, Fakultas Kedokteran, Universitas Islam Indonesia. 2007

9. Notosutardjo, I. Hubungan Antara Karakteristik Pasien dengan Kualitas Pelayanan, Kepuasan dan Kepatuhan Pasien di Klinik Penyakit Dalam Instalasi Rawat Jalan Rumah Sakit Islam J akarta Timur, Tesis, J urusan IImu-IImu Kesehatan Program Pascasarjana, Universitas Gadjah Mada. 1999

10. Pohan. Jaminan Mutu Kesehatan, EGC : J akarta. 2007 